\title{
Folk Beliefs and Popular Tales
}

We suspect we are not the only people to misremember the plot of Frankenstein. The layering upon the novel of countless films and popular cultural references left us with a vague memory that the monster was created from criminal corpses, reanimated by the power of galvanism. Its subsequent pursuit of Frankenstein's friends and family was, we seemed to remember, the product of its atavistic, criminal nature bubbling through. It was a parable about the arrogance of a man trying to usurp the work of the creator, and the impotence of human design to reshape the essence of things and people.

On re-reading the novel, however, many years after we first encountered it, we realised how partial and distorted our memories of it were. The monster was created using chemistry and, it is implied, the already discredited alchemical ideas of Cornelius Agrippa and Paracelsus. Author Mary Shelley is unspecific about where the materials come from, beyond saying that Frankenstein 'collected bones from charnel-houses and disturbed, with profane fingers, the tremendous secrets of the human frame'. 'The monster's viciousness was a result of hurt and anger, produced by his cruel exclusion from human communities of love, not an expression of a criminal essence, though Victor Frankenstein fails to understand this.

It was therefore no part of Shelley's vision that criminality inheres in the body. Nevertheless, that idea has been attractive to the authors of

S. Tarlow and E. Battell Lowman, Harnessing the Power of the Criminal Corpse, Palgrave Historical Studies in the Criminal Corpse and its Afterlife, https://doi.org/10.1007/978-3-319-77908-9_8 
later reworkings of the Frankenstein narrative. At issue is a key question about what constitutes a criminal corpse: the origin and nature of criminality. This was a divisive problem in the nineteenth century. It was essential to Enlightenment ideas of human character and behaviour that people are shaped by their environments. They are thus susceptible to education and capable of almost infinite improvement. ${ }^{2}$ Robert Owen, for example, published a series of essays on human character, developing the principle that 'Any general character, from the best to the worst, from the most ignorant to the most enlightened, may be given to any community, even to the world at large, by the application of proper means' ${ }^{3}$ On the other side of the table, especially as the nineteenth century progressed, were the adherents of the developing sciences of human behaviour: the disciplines which would eventually become anthropology and psychology. Their precursors, phrenology, physiognomy and early biological anthropology relied on anthropometry to reveal capacity, ability and character. These were very much written in the body, inescapable and congenital. Criminality in this paradigm was an inevitable quality of 'bad blood', poor breeding that no amount of better housing and universal education would be able to eradicate.

The implications of taking an 'environmental' or 'congenital' view of criminality are great and this book is not the place to open them up much further. However, the currency of this debate in the nineteenth century affected and informed many of the cultural products of the period. The political sympathies of authors are manifested in their approach to criminality: environmentalists being inclined to stories that emphasise the difficult conditions which give rise to criminal behaviour; more conservative stories focusing instead on the early manifestations of individual Bad Character in people who matured into full-blown villains. ${ }^{4}$

The power of the executed corpse can be channelled not only through the deployment of the material body and its constituent parts, though that has been the focus of most of this book so far, but also through its evocation in stories, visual media and other forms of representation. This chapter looks at the cultural afterlives of criminal bodies. While some of these are the histories of body parts that have been reappropriated and transformed, such as the curious power of the hanged man's hand, considered in the previous chapter, other afterlives are the products of a creative cultural imagination: songs, stories, plays and films. 


\section{The Criminal Corpse in Literature}

During the period of the Murder Act the executed body in a gibbet seems to have caught the imagination of writers to a greater degree than that of the body under dissection. This imbalance was largely reversed in the periods before and after this. Early modern writers were obsessed with the process of dissection and anatomisation; anatomy was a ubiquitous metaphor in the poems, plays and essays of the period, as demonstrated by Jonathan Sawday, ${ }^{5}$ and in the twentieth and twenty-first centuries the interest of cultural historians in opening bodies has informed the work of novelists and others too. Gibbets, on the other hand, have been almost absent from the historiography, and their representation in popular culture, when it occurs, is a mishmash of misunderstandings, a pastiche of a homogenous 'olden days' in which pirates are left to starve in birdcages along the coast.

Stories of criminal corpses and their fates occur throughout the post-medieval period. These range from the well-informed and profound ruminations of Donne in the early modern period, to anonymous ballads and pamphlets. ${ }^{6}$ This chapter explores some of these literary afterlives.

\section{The Gibbet in Literature}

John Grindrod was gibbeted in 1759 on Pendleton Moor in Lancashire for poisoning his wife. The ballad 'Old Grindrod's ghost', collected by William Ainsworth in 1872, tells a story that recurs with variants around the country. The full text of the ballad is as follows:

Old Grindrod was hang'd on a gibbet high,

On a spot where the dark deed was done;

'Twas a desolate place, on the edge of a moor,

A place for the timid to shun.

Chains round his middle, and chains round his neck.

And chains round his ankles were hung;

And there in all weathers, in sunshine and rain,

Old Grindrod the murderer swung.

Old Grindrod had long been the banquet of crows,

Who flock'd on his carcase to batten;

And the unctuous morsels that fell from their feast,

Served the rank weeds beneath him to fatten. 
All that's now left of him is a skeleton grim.

The stoutest to strike with dismay;

So ghastly the sight, that no urchin, at night,

Who can help it, will pass by that way.

All such as had dared, had sadly been scared,

And soon 'twas the general talk,

That the wretch in his chains, each night took the pains.

To come down from the gibbet-and walk!

The story was told to a traveller bold.

At an inn near the moor, by the host;

He appeals to each guest, and its truth they attest,

But the traveller laughs at the ghost.

'Now to show you,' quoth he, 'how afraid I must be,

A rump and a dozen I'll lay.

That before it strikes one, I will go forth alone,

Old Grindrod a visit to pay.

'To the gibbet I'll go, and this I will do,

As sure as I stand in my shoes;

Some address I'll devise, and if Grinny replies,

My wager of course I shall lose.'

'Accepted the bet; but the night it is wet,'

Quoth the host. 'Never mind,' says the guest;

'From darkness and rain the adventure will gain

To my mind an additional zest.'

Now midnight had toll'd, and the traveller bold

Set out from the inn all alone;

'Twas a night black as ink, and our friend 'gan to think That uncommonly cold it had grown.

But of nothing afraid, and by nothing delay'd, Plunging onward through bog and through wood.

Wind and rain in his face, he ne'er slacken'd his pace, Till under the gibbet he stood.

Though dark as could be, yet he thought he could see The skeleton hanging on high;

The gibbet it creaked, and the rusty chains squeaked, And a screech-owl flew solemnly by. 
The heavy rain patter'd, the hollow bones clatter'd.

The traveller's teeth chatter'd—with cold—not with fright;

The wind it blew lustily, piercingly, gustily;

Certainly not an agreeable night!

'Ho! Grindrod, old fellow!' thus loudly did bellow

The traveller mellow,-'How are you, my blade?'

'I'm cold and I'm dreary; I'm wet and I'm weary;

But soon I'll be near ye!' the skeleton said.

The grisly bones rattled, and with the chains battled;

The gibbet appallingly shook;

On the ground something stirrd, but no more the man heard-

To his heels on the instant he took.

Over moorland he dash'd, and through quagmire he plash'd;

His pace never daring to slack;

Till the hostel he near'd, for greatly he fear'd,

Old Grindrod would leap on his back.

His wager he lost, and a trifle it cost;

But that which annoy'd him the most,

Was to find out too late, that certain as fate,

The landlord had acted the ghost.

The story of the boastful man at the inn getting his comeuppance at the foot of the gibbet is a widely known one, and variants relate to other gibbets and other vainglorious travellers. The same story is told of Matthew Cocklane, executed in Derby in 1776 and others. ${ }^{7}$ A letter to The Mirror of Literature, Amusement and Instruction locates the story to Craven and the gibbet of 'Tom Lee', and the victim of the joke is a retired sergeant, given to rambling and boastful accounts of his military career. ${ }^{8}$ The Mirror's correspondent pertinently remarks that the murderer had almost as strong and frightening a hold over the imaginations of ordinary people after he had been gibbeted as he had before he was caught: 'Though the strong arm of the Law had incapacitated this desperado from any further molestation of person or property, yet over the minds of the superstitious and the ignorant, he seemed to have a greater dominion than ever'. ${ }^{9}$ It is a popular piece of gibbet lore, perhaps especially in the nineteenth century when actual gibbetings were very infrequent and their occasions drew huge crowds and much public interest. 
The ballad or broadside was the cheapest, most popular, and least accomplished literary form during the period preceding and during the Murder Act. Broadsides of true crime and punishment were perennially popular, even into the later nineteenth century (and indeed the True Crime sections of modern bookshops remain their large and well-frequented successors). In a tradition spanning from the sixteenth to the nineteenth centuries, cheap, sensational accounts of the crimes and fates of notorious offenders were produced rapidly to coincide with the peak of public interest in the case. Typically they contain a ballad of poor literary quality and, especially in the eighteenth and nineteenth centuries, a prose account of the affair. Illustrations, when they occur, are generic woodcuts; frequently the same prints are used repeatedly for decades or even centuries. Broadsides about mid-nineteenth-century criminals might be accompanied by a woodcut of individuals in seventeenth-century costume. Interestingly, with the end of hanging in chains and the gradual removal of punishment from public view, crime ballads also came to focus more on the crime and its forensic solution, while executions disappear from the story after around $1830 .{ }^{10}$

Literary treatments of real criminal cases were not uncommon throughout the period, though the dead body or post-mortem punishment of an executed criminal features less frequently. Eugene Aram, for example, who was hung in chains following his conviction for murder in 1759 became a celebrity more than sixty years after his death because of the publication of two massively popular literary works about his life and execution in the 1830s. Eugene Aram was an educated man, working in a school in Norfolk, when he was arrested for a murder that had taken place fifteen years earlier, and in a case where no body had been found. A former associate of Aram's named him as the culpable party and, on very slender and unreliable evidence, Aram was found guilty and sentenced to be hung in chains after execution. Fictionalised retellings of his life, crime, flight from justice, and eventual trial and execution were produced from the imagination of poet Thomas Hood and popular novelist Edward Bulwer Lytton. Thomas Hood's narrative poem 'The Dream of Eugene Aram' was first published in 1831 and is a ruminative account of Aram reflecting on his life and crime in the moments before his arrest, finishing with him being taken away for trial. ${ }^{11}$ Bulwer Lytton's Eugene Aram, published the following year, ${ }^{12}$ is ludicrously melodramatic and sentimental for modern tastes but nineteenth-century English speakers 
around the world lapped it up. These two stories of Eugene Aram were both bestsellers; the novel was adapted for the stage and was the inspiration for a series of prints by Gustav Doré. Aram thus remained the object of popular interest well into the twentieth century. PG Wodehouse even has Bertie Wooster quoting Hood's poem in proper Wooster style:

All I can recall of the actual poetry is the bit that goes: Tum-tum, tumtum, tum-tumty-tum, I slew him, tum-tum tum! ${ }^{13}$

However, in neither of these works does the executed body of Aram play a significant role. Hood's poem finished before Aram's trial, and BulwerLytton's novel leaves Eugene at the moment of his death. His sentencing is not mentioned, beyond execution, and neither Aram himself nor any of the other characters reflect on hanging in chains.

During the nineteenth century, even after hanging in chains had mostly died out as a punishment, the continuing presence of gibbets in the landscape seems to have made the gibbeted body a powerfully meaningful and memorable part of local landscapes, and as such it is frequently described to add atmosphere or to serve a symbolic role in nineteenth-century literature.

The body itself could be entirely gone or reduced to bones without the material structure of the gibbet losing its power to terrify and fascinate. The opening paragraphs of Charles Dickens's Great Expectations refer to young Pip's experience of the gibbet on the marshes where he encounters the escaped convict Magwich. ${ }^{14}$ The gibbet is a landmark in the featureless wetlands, even though the name of the man who hung there is forgotten or unspoken. ${ }^{15}$ It is emblematic, even anonymously, of the consequences of crime that haunt and drive the plot of the novel. By contrast, anatomised bodies barely feature in Dickens's work, though the procurement of (noncriminal) corpses for dissection was part of the livelihood of Gerry Cruncher in A Tale of Two Cities. ${ }^{16}$

For William Wordsworth in 'The Prelude', the gibbet appears as a significant childhood memory. An unexpected encounter with a gibbet during an adventurous expedition constitutes one of the poet's first shocking and macabre encounters with mortality:

$\ldots$ and I fled,

Faltering and faint, and ignorant of the road ${ }^{17}$ 
Duncan Wu notes that 'Nicholson's gibbet [the one that best fits the geography of Wordsworth's childhood recollections at this point] had not 'mouldered down' in 1775 , and a 5 -year-old would not have ridden that far'. ${ }^{18}$ Kelley considers that the gibbet was either at Gibbet Moss near Hawkshead or Penrith Beacon. ${ }^{19}$ However, it is not the historical accuracy of this episode that matters as much as its symbolic power. The boy Wordsworth is both innocent and naive; the gibbeted criminal represents the worst of human evil, and his punished corpse is a sign of the brutality of social and political institutions. The presence, in the midst of a beautiful, rural landscape, of a decaying body, and the body of a murderer at that, disrupts any naïve pastoral idealism, and gives a dangerous, Romantic force to the hills and lakes of the young poet's early life.

Perhaps the fullest nineteenth-century fictional account of a child's encounter with an English gibbet was not written by an English person at all, but a Frenchman, albeit in a novel set in England. Victor Hugo's L'bomme qui Rit (literally, The Laughing Man, though published in English as 'By Order of The King') was first published in 1869. The story follows the life of Gwynplaine. Stolen as a baby and mutilated by having the corners of his mouth cut up towards his ears to give him a permanent grin, ${ }^{20}$ Gwynplaine finds himself wandering alone in southern England. Eight-year-old Gwynplaine's encounter with the gibbet takes place at dusk on a winter's day as the child walks along the cliffs of the south coast of England. Although Hugo's novel was set in England, the author himself was, of course, French, and his account of eighteenth-century practice, a century later and a country removed, might not be entirely accurate. However, references to Jack the Painter, ${ }^{21}$ and some other historical details, such as the three men still hanging in chains at Dover castle in $1822,{ }^{22}$ suggest that this chapter was well researched.

The gibbeted man encountered by young Gwynplaine was tarred and partially decayed. However, Hugo describes traces of repair and maintenance that had been carried out on the body, suggesting that it had been freshly retarred. The tar here functions to prolong the existence of the man: 'They had not cared to keep him alive, but they cared to keep him dead. ${ }^{23}$ Hugo suggests that extending the man's tenancy of the gibbet would postpone the moment at which a new example must be made. The coastal gibbets of smugglers were intended, says the narrator, to act as 'beacons' to other smugglers, although these beacons did not deter crime, and Hugo's choice of word (réverbère, which as a noun means 
lamp-post or streetlight) implies instead that the conspicuity of the gibbet might have inadvertently assisted the smugglers in finding their way along dangerous coasts with few landmarks. The two most striking aspects of this encounter are, first, the way the gibbeted corpse occupies a liminal space between life and death; and second its multisensory apprehension by the onlooker. Gwynplaine's encounter with the gibbet is an immersive and bodily experience.

The body, as the child apprehends it, is neither wholly alive nor wholly dead, but instead exists in some terrifying liminal state. Though skeletal, and its eyes, nose and mouth no more than 'holes', his teeth 'retained a laugh' and his drooping head seemed somehow alert. ${ }^{24}$ The child feels keenly an absolute horror of being regarded by blind eyes that 'seem to have vision', as he succumbs to a debilitating terror. Then the wind begins to blow the gibbeted man back and forwards; there is, observes Gwynplaine '[n] othing stranger than this dead man in movement. ${ }^{25}$ As the dead man swings faster and further, the chain from which he is suspended makes a disturbing grinding noise, like breathing. As the wind increases the grinding cry becomes a shriek. Then, out of the gathering evening and storm, a flock of ravens appears ${ }^{26}$ and the birds perch first on the gibbet and then on the corpse itself. In a particularly grotesque passage, the black birds swarm over the body, which is now a writhing form of black wings, beginning to move with renewed energy in the returning storm. The body seems to struggle in 'convulsions' and Gwynplaine has the impression that the man is trying to escape his cage, 'possessed with hideous vitality. ${ }^{27}$

Hugo's gibbeted man occupies an intermediate space between life and death. Though a dead thing, it moves and makes noises like a living person. Its blind eyes can see; its empty mouth laughs at him.

Looking back on the gibbet from the later nineteenth century, A. E. Housman is almost nostalgic for the gibbet which formerly stood 'Fast by the four cross ways'. He contrasts the place where a hundred years before the dead criminal 'stood on air' above the moonlit sheep, with the mechanical long drop hanging inside the walls of Shrewsbury Jail. ${ }^{28}$ The gibbet of Housman's imagination fits into a romantic landscape of 'moonlit heath and lonesome bank' more naturally than the quick end of the prison execution, accompanied by the 'groan' and whistle of trains that run through the night. Although Housman adds a footnote to explain that 'keeping sheep by moonlight' was a euphemism for hanging in chains, it is not an expression we have encountered elsewhere. 
A fictional gibbet appears in the children's moralising book of religious education The History of the Fairchild Family, written by Mrs. Sherwood and published in 1853. The nauseatingly pious Mr. Fairchild takes his children, aged seven, eight and nine, to see the remains of a murderer hanging on a gibbet a few miles from their home. This trip is intended to act as a cautionary tale, following a squabble between the children. Their father tells the story of how Roger, the man whose remains they have come to see, was brought up in a misguidedly permissive household and eventually quarrelled with and killed his own brother. Although the children have already been punished for their argument, and have expressed their regret, Mr. Fairchild decides they should be taken to the gibbet at Blackwood to see something 'they will remember as long as they live: and I hope they will take warning from it, and pray more earnestly for new hearts, that they may love each other with perfect and heavenly love'. ${ }^{29}$

\section{The Melancholy of Anatomy}

The literary weight and significance of anatomical dissection has received extensive critical attention, especially the cultural production of the early modern period. However, the criminality of the body that is being dissected is not necessarily, or even normally, considered in literature. Anatomical dissection was not only vastly interesting in itself to the writers and artists of early modernity, the process of dissection-opening, laying visible, describing and exploring in an ordered fashion-became a defining metaphor in the period. 'Anatomies' of subjects as diverse as Popish Tyranny, Wit and Fortune were published in the period 15761650. Richard Sugg lists 78 titles containing the word 'anatomy' in a metaphorical sense dating to that period, and a further 44 which use 'anatomise' as a verb. ${ }^{30}$ As Sawday has described, this kind of anatomy is analogous to geographical exploration: a noble, courageous and selfless endeavour carried out to the betterment of humankind. ${ }^{31}$ To anatomise is to know, describe and map in detail an area that had been improperly, incompletely and impressionistically known before. It is itself a 'civilising' act, in the sense of bringing the unknown realms of Nature or the Mind of God into the control of Man. The tension between knowledge that is properly God's and that which should be brought into human understanding is an important motor of early modern writing on the subject of anatomy. 
There was nothing necessarily criminal about the dissected bodies of these anatomies, but a dread of being anatomised was harnessed to drive both moralising tracts and works of comedy. Both Sugg and Sawday mention popular comedies and melodramas, such as The Atheist's Tragedy (Cyril Tourneur 1611) and The Anatomist (Edward Ravenscroft 1696), which employ a threat of anatomisation to give urgency and an entertaining frisson to the action. In these popular works the would-be anatomiser has no nobility of purpose. Instead, the 'Atheist' of Tourneur's work is driven by a heretical desire to uncover knowledge that properly belongs to God alone. The central character requests the body of his courageous nephew so that he can find 'in his anatomy' where his bravery is located. This demonstrates both that a belief in the somatic basis of character could be articulated in 1611, and that such a belief was condemnable as impious and immoral.

In the early eighteenth century, the corpse under anatomical exploration could provide an element of dark, transgressive humour in popular culture, juxtaposing the solemn and forbidden nature of the corpse with a trivial personal or romantic goal. In Alexander Pope's satirical Memoirs of the Extraordinary Life, Works, and Discoveries of Martinus Scriblerus, published in 1741, pedantic scholar Scriblerus tries to acquire a criminal corpse in order to study anatomy. The servant tasked with its procurement is trying to drag the body secretly upstairs. As the body threatens to slip from his grasp, he tightens his grip around its abdomen. This has the unfortunate effect of causing the cadaver to expel a quantity of gas in a loud and vibrant fart. In terror, the man abandons his job and runs away, leaving the neighbours, aroused by his shrieks, to discover a corpse on the stairs. Assuming that a murder has been newly discovered, they summon the watch, who capture Scriblerus and his unfortunate servant. The would-be anatomists are taken to see the Justice, who asks what their profession is. The servant declares, in an abominably poor attempt to exonerate them, 'It is our business to imbrue our hands in blood; we cut off the heads, and pull out the hearts of those that never injur'd us; we rip up big-belly'd women, and tear children limb from limb'. ${ }^{32}$

Where dissection or anatomy is featured in nineteenth-century fiction, the emphasis is invariably on the dreadful experience of the cadaver, or the ghoulish appearance of the corpse as a thing to terrorise the living, to horrifying or comic effect. There is no sense here that the criminal bodies are being sacrificed to further some higher goal or greater good of improving medical care or developing surgery. The exploration of the body's interior 
in the time of the Murder Act is no longer the noble, humanistic voyage celebrated by Donne two hundred years earlier (Donne consistently uses the language of geographical exploration to describe knowledge of the body). It is desecration motivated by prurience.

The anatomised corpse rarely appears in fiction, except as an object of comedy or horror. In deSade's La Marquise de Gange (1813), for example, the eponymous marquise is being held prisoner in an old castle. She notices that the door to a previously locked room has been left ajar and, driven by curiosity, goes into the room. Inside she encounters a 'horribly mutilated' cadaver, which was in the process of being dissected in a private anatomy room. ${ }^{33}$

\section{The Magical Corpse}

The dead body has specific powers in early modern literature, particularly judicial and curative powers. The medicinal power of the body in history has been extensively explored in history by Sugg and by Davies and Matteoni, and in literature by Robert Brittain. ${ }^{34}$ The judicial power of the dead body lay not so much in the criminal corpse as in the body of the victim. The belief that the cadaver of a murder victim would bleed afresh in the presence of its murderer was known in ancient texts, ${ }^{35}$ but occurs in historically documented cases until the nineteenth century, and is important to the plots of Shakespeare's Richard III, ${ }^{36}$ and Walter Scott's Fair Maid of Perth. ${ }^{37}$ That it was well known beyond Britain is evident in Mark Twain's The Adventures of Tom Sawyer, when Tom hopes that the bleeding of Dr. Robinson's body would turn suspicion towards Injun Joe, as the dead man was lifted onto a wagon. ${ }^{38}$ Davies and Matteoni point out that the judicial power of the phenomenon of post-mortem bleeding (properly called 'cruentation'), demonstrates a belief in the sympathetic link between the dead victim's body and that of the living criminal. 39

The medicinal power of the criminal corpse, considered in the previous chapter, is less explored in literature, though the quest to obtain a touch of the dead man's hand provides the narrative drive in Thomas Hardy's short story The Withered Arm. In that story, a woman, sensing that her new husband is preoccupied and seems less interested in her, concludes that he feels revulsion at her withered arm and seeks out a cure. As orthodox medicine has failed her, she secretly goes to the assizes in the county town in order to apply the touch of the dead man's 
hand, and negotiates access to the body of a freshly executed criminal. Unexpectedly she meets her husband by the side of the cadaver: the hanged man is her husband's son from his first marriage, and keeping quiet about his knowledge of his son's fate, rather than distaste for his wife's deformity, explains his subdued demeanour.

The hand of the hanged man had other powers beyond the curative. The tradition of the 'hand of glory' is well known in folk stories (Fig. 8.1). Shane McCorristine gives a version of the tale as follows, though there are numerous variants known as ballads or collected by folklorists in the nineteenth century. ${ }^{40} \mathrm{~A}$ traveller asks to leave a box overnight in the house of a wealthy farmer. In the middle of the night, the maidservant, unable to sleep, goes downstairs and is alarmed to see a tall man remove from the box a withered human hand. He then proceeds to fix the hand to a board, and smear it all over with some kind of grease, and then to set fire to the fingers so that they burn like candles in a candelabra. The man then begins to burgle the house. The maid runs upstairs to wake the sleeping members of the household but is unable to rouse

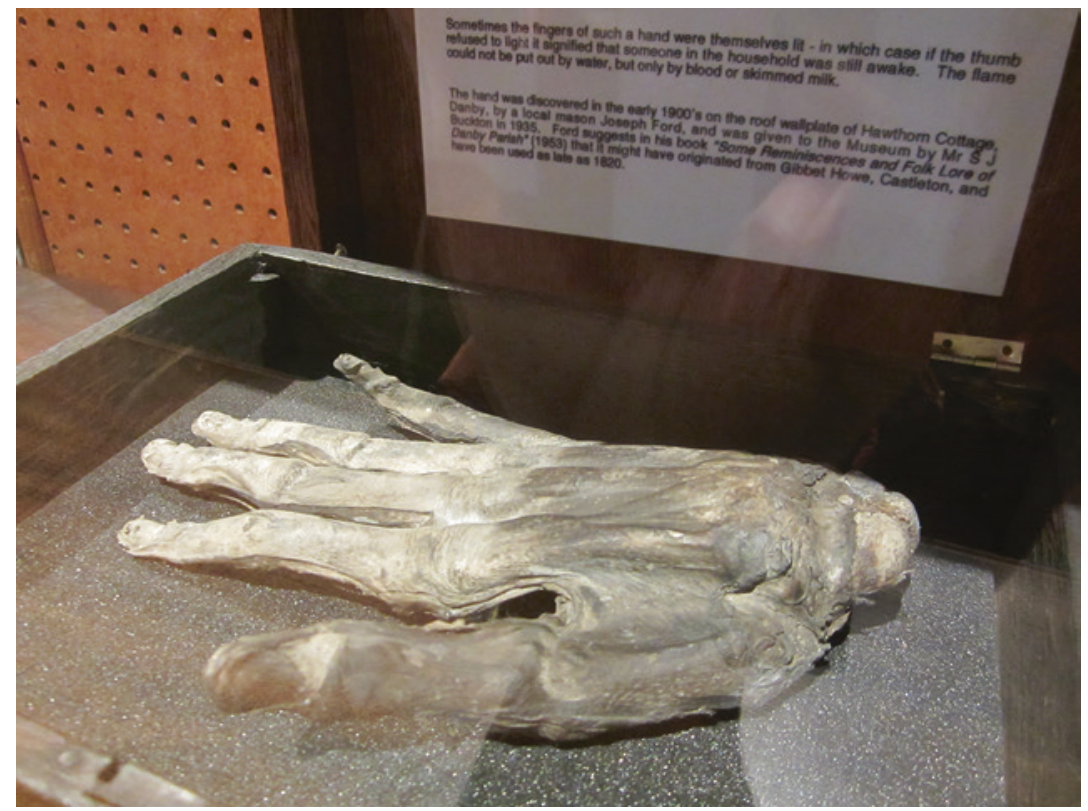

Fig. 8.1 Hand of Glory, Whitby Museum (Sarah Tarlow) 
them at all. Returning downstairs, she tries to extinguish the burning hand, but water seems to have no effect. Remembering something she had once heard, she takes a jug of milk and throws that over the hand of glory which happily extinguishes the flames. Now the enchantment is over, the family wakes up and the thief flees, empty-handed.

Details differ from this version, which was collected by a correspondent writing about the folklore of Cheshire in 1872. In other versions, the burglar is a traveller disguised as a woman, seeking shelter at an inn, or the hand acts as a candle holder for a candle made from human fat and other magical ingredients, rather than burning itself; but the details of the nefarious use of the hand, its origin as part of a hanged criminal, the unwakeable sleep of the inhabitants and the resourcefulness of the servant remain the same. The power of the hand of glory was sufficiently well known that it featured in works of nineteenth-century literary fiction, including Walter Scott's The Antiquary (1816) and Richard Harris Barham's The Ingoldsby Legends (1840). Scott actually gives detailed instructions for how to make a hand of glory, which he puts into the mouth of Westphalian Mr. Dousterswivel:

it is hand cut off from dead man as has been hanged for murther, and dried very nice in der shmoke of juniper wood, and if you put a little of what you call yew wid your juniper, it will not be any better-that is it will be no worse- then you do take something of de fatsh of de bear, and of de badger, and of de great eber, as you call de grand boar, and of de little sucking child as has not been christened (for dat is very essentials), and you do make a candle, and put it into de hand of glory, at de proper hour and minute, and with de proper ceremonish, and he who seeksh for treasuresh shall never find none at all. ${ }^{41}$

The power of the criminal corpse could, alternatively, be mediated by objects or things that had 'caught' the power of the body itself. The body's power could pass into other things through contagion, proximity or sympathy. The power of the hangman's rope has been discussed by Matteoni, and Davies and Matteoni. ${ }^{42}$ Hangmen were able to make some money by selling lengths of the rope used for a hanging as a remedy or safeguard against illness. Matteoni and Davies also note the associations of the criminal corpse with the magical and medical power of the mandrake, which was important in some works of literature. The mandrake grew, by tradition, beneath the gallows, where it was nourished by, and imbued with power from, the corpse hanging above it and 
dripping blood or other powerful bodily fluids onto the ground. The mandrake tradition appears in European literature from around 1500. ${ }^{43}$ In Ludwig Achin von Arnim's Gothic tale Isabella of Egypt, a beautiful Gypsy princess creates a magical creature-a mandragore-by bringing to life a mandrake that had grown beneath the gallows on which hung the body of her father, fed by his tears. The mandrake creature-called Mandragore-is an evil being but in the service of Isabella, and has the ability to find buried treasure, of which Isabella needs a plentiful supply if she is to achieve her goal of marriage to the crown prince.

During the nineteenth century, the dead criminal continued to exert power and to be co-opted into other ideological projects, especially within the growing spiritualist movement. Spiritualists believed that the dead occupied an imminent geography 'beyond the veil' or 'on the other side'. Communication between the dead and the living could be facilitated by mediums who were sensitive to the presence of dead souls among us. Among the spiritualists, the traditional opportunity for the about-to-be executed to express last-minute repentance of their evil deeds could now be extended into the post-mortem period. The executed could, through a medium, express remorse, and give moral or practical instructions to their friends and family. For example, William Saville was executed in 1844 in Nottingham for the murder of his wife and three children. Indirectly, he was responsible for the deaths of many more, as at least 16 people were crushed to death in the crowd that surged along Nottingham's narrow streets and down its stone steps following Saville's execution in front of Shire Hall. Saville's spirit, however, appeared to spiritualist medium John G.H. Brown in a crystal ball. He confessed to his crimes and described his existence in the 'lower regions' (a kind of 'Hell-lite' ${ }^{\text {'4 }}$ for a sect that did not believe in everlasting damnation, but required a place where sins could be paid for and regretted). ${ }^{45}$ Spiritualists generally opposed capital punishment altogether on the grounds that God had determined an allotted span for every person, and curtailing that period left the spirit of the departed in a kind of protestant limbo until the time of what would have been their natural death.

\section{The Criminal Corpse in ArT}

Many artistic depictions of criminal bodies are incidental to other illustrative purposes: gibbets on maps and town plans, for example, or heads on spikes above a gate, bridge or wall in early modern town views. 
In the Middle Ages, and indeed afterwards, the referent for almost all depictions of the criminal corpse was the body of the crucified Christ, or the bodies of the criminals who died beside him, as was discussed in Chapter 2. The cross casts a long shadow, and well into the early modern and modern age, depictions of criminal bodies were self-consciously positioned with reference to the very deep tradition of presenting the criminal body as at once abject and an object of salvation.

The anatomised criminal corpse has a lower profile in textual afterlives than in visual art. The changing depictions of anatomical dissection are evident in a comparison between two very well-known and much reproduced images, separated by 120 years: Rembrandt's painting The Anatomy Lesson of Dr. Nicolaes Tulp (1632) and Hogarth's etching The Reward of Cruelty (1751). That the first of these is a commissioned group portrait, worked in oils, and the second a popular grotesque is in itself significant. What had been possible to represent heroically in the seventeenth century was now quite the reverse.

In early modernity, some of the best-known and most widely reproduced images are Rembrandt's paintings of bodies under dissection. His Anatomy Lesson of Dr. Nicolaes Tulp is a commissioned group portrait, worked in oils. In this picture, the object of study is the body on the table, but the body here is sympathetically represented. While the body is clearly inanimate, and contrasted with the lively curiosity of the gentlemen gathered around, the prostrate and pale form, covered with a loin cloth, is reminiscent of Christ taken down from the cross. The drooping head and foreshortened perspective of the criminal body in Rembrandt's other well-known anatomy painting, The Anatomy Lesson of Dr. Joan Deyman, further evokes Christ on the cross. The sacrificial and redemptive associations of the criminal corpse are clear in both of these pictures, but so also is the heroism of the anatomist. ${ }^{46}$ Heckscher argued that Rembrandt worked with the gentlemen commissioning the portrait of themselves with Dr. Tulp to represent the doctor as a transformative and benevolent figure, transforming the dangerous, criminal, deviant threat to ordered society into progressive and benevolent knowledge. ${ }^{47}$

Such a representation was no longer possible in the cynical age of Hogarth. 'The reward of cruelty' is the fourth of a series of four etchings depicting the life of fictional anti-hero Tom Nero (Fig. 8.2). His childhood cruelty to animals has matured into violent and murderous cruelty to people, and in this final episode an ironic reversal of fortune has occurred and Nero's own body has become the subject of violent action. The medical men who crowd around the dissection are taking 


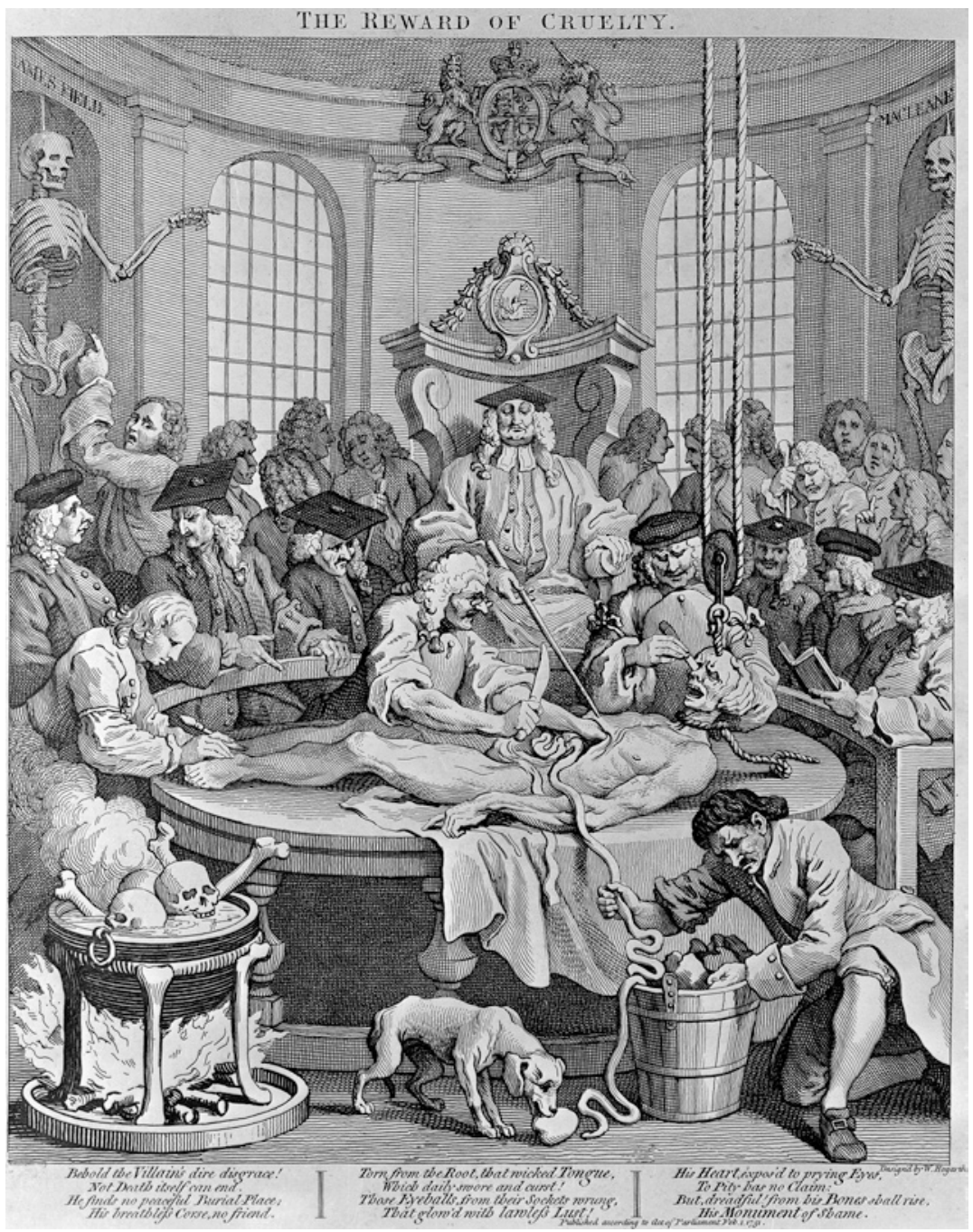

Fig. 8.2 The Reward of Cruelty. William Hogarth 1795 (Wellcome Collection)

a greedy and unseemly joy in the destruction of Nero's body. Although dead, the body is being hoisted up so that he seems to be responding to the physical discomfort and indignity of the procedure. There is a comic and grotesque suggestion that the body is being prepared as food. 
A cauldron of boiling bones is evidence that the remains of the current subject of study will join the articulated and mounted specimens displayed in niches around the room. Disgustingly, a dog is nosing at the man's heart and entrails: canine revenge for Nero's juvenile torture of an unfortunate puppy. Hogarth's dissection scene is a thousand miles from the respectable, scholarly anatomies of Rembrandt. There is no suggestion that a higher purpose of advancing scientific or medical knowledge is being served. The men attending the dissection vary in their responses. Some are bored or distracted, some appear over-eager or pompous, though none looks as animated, ironically, as the subject of investigation.

Dissection in Hogarth's London in the 1750s has a very different character to Rembrandt's Amsterdam anatomies of a century earlier. The difference between the two, however, is not a simple chronological progression. As we have seen, literary and dramatic representations of anatomy in the seventeenth century understand it predominantly as a macabre and grotesque practice, the social context of which is more likely to be a conjunction of a base criminal in need of the worst kind of punishment with an arrogant devotee of a ghoulish art. Thomas Nashe's picaresque The Unfortunate Traveller [1594] sees the hero, Jack Wilton, in a scene which is both revolting and comic, faced with the prospect of becoming 'an anatomy' and sliced open 'like a French summer doublet'. In his survey of early modern literary treatment of dissection and anatomy, Sugg notes that in the seventeenth century the vocabulary of cadavers is still plastic and unfamiliar ${ }^{48}$ : the word 'skeleton' requires glossing, even in tracts with an educated readership, and 'an anatomy' might refer to a preparation, a skeleton or even to gibbeted remains.

\section{INTO MODERNity}

Until at least the end of the eighteenth century, anatomy was intimately connected' to the criminal process. ${ }^{49}$ Possibly it was not until after the Anatomy Act and the formal removal of the criminal corpse from anatomical attention that anatomy was widely acknowledged to be a useful and legitimate science, and its practitioners to be motivated by benevolent research rather than impious glee in gore. But in the nearly two centuries since the Murder Act was formally repealed, writers, artists and, latterly, filmmakers have continued to invoke the criminal corpse as an emotionally powerful vehicle upon which to make political, social or symbolic points. 
In contemporary art, film and literature, it is almost impossible to represent bodies that suffer excruciating pain or humiliation unsympathetically: the suffering body itself is such a powerfully freighted image that it can be used in fact as an emotional short-cut directly to the empathetic heart of the audience. In modern film history, the criminal corpse rarely features. Aggravated executions are significant motifs of some films, and are always redemptive in character. This is obvious in the films of Mel Gibson, such as The Passion of the Christ, and the Christian narrative is appropriated in the construction of a romanticised nationalist myth in Braveheart. ${ }^{50}$ 'Braveheart' tells the story of William Wallace, leader of a Scottish rebellion against the English in the thirteenth century, whose eventual execution for treason was described in Chapter 2. There is little subtlety in the political history of the film: the English are almost universally despicable, greedy, violent, cowardly and effeminate. The Scottish nobles are self-interested and perfidious. However, all the ordinary folk of Scotland are brave, honest, selfless, charming and handsome, most of all Wallace himself, played by Mel Gibson who also directed the film. His intelligence, attractiveness, superiority as both a soldier and a lover are heavily played off against the effete, cruel English kings. Eventually, Wallace is betrayed to the English and convicted of treason, which means he is to be punished by hanging, drawing and quartering. Wallace faces death with dignity and refuses to show penitence or declare allegiance to the English king, even under torture. This has the effect of bringing the originally hostile crowd around to his side as they recognise his strength of character, the legitimacy of his cause and manliness of his conduct. After Wallace's execution, during which he is consoled not by a medieval vision of Christ or by religious sentiments, but by a very modern apparition of his dead wife, a voiceover tells the audience that Wallace's body was quartered and the parts sent to the rebellious towns of Scotland, but that they failed to subdue the freedom-loving hearts of the Scots, instead inspiring them to further resistance. The final scene shows Robert the Bruce, who throughout the drama has been torn between serving the narrow interests of his family and the greater glory of his nation, leading the Scots to victory at Bannockburn.

The great distance between 'Braveheart' and known historical fact has been widely described. Many have also felt uncomfortable with the violently nationalist and homophobic message of the film. However, it was massively popular worldwide and its story and characters were appropriated by sports teams and commentators, political parties, tourist boards 
and many others with goods to sell or ideologies to promote. Colin MacArthur reviews these appropriations. ${ }^{51}$ 'Braveheart' consciously fits the death of Wallace to the crucifixion of Christ. During a painfully protracted death sequence, Wallace is strapped to a cross, resists the temptation of a diabolical 'confessor' who presses him to deny his cause, and eventually expires with the vision of his lost love miraculously before his eyes, and the word 'freedom' on his lips.

Nine years later, Gibson returned to the source, and once again depicted a martyrdom, this time the paradigm of the suffering body: the crucifixion of Jesus Christ. The Passion of the Christ was an ambitious and cinematic filmic depiction of the last hours of Jesus's life. It has been criticised not only for being excessively bloody, but also for its antisemitism (as with the English in Braveheart, the Jews in The Passion of the Christ are ugly and unmanly). But again, it shows the difficulty of representing physical suffering without exciting the sympathy and horror of the audience. Aside from Jesus Christ's own death and resurrection, even the thieves crucified alongside him-properly criminal corpses-are not moral lessons so much as objects of our compassion.

\section{Popular Belief, Cultural Production and Punitive Force}

Was anatomical dissection a thing of such horror because it was a punishment for the worst of criminals? Or was it an extreme punishment because it was a thing of such horror? The answer is that it was both. The terror of being dissected was recursively produced alongside the shame and dread of criminal punishment in a complex and shifting dance of cultural meanings. Dissection was dreadful because it was humiliating, and in that capacity belongs to the tradition of punishment by public shaming; but it was also terrifying in a less logical and more visceral sense because of the slippage in imagination between the scalpel in the cadaver and the knife in the living body. Being cut was always horrific. Sugg's book of 2007 is entitled Murder after Death, a title that expresses well the terrors of post-mortem dissection. Two factors made the idea of cutting into the body especially horrific in early modern England. The first is that, as Katharine Park has described in relation to an earlier period, the newly dead in northern Europe, unlike their counterparts in Italy, were considered to be in the process of dying. Rather than being instantly blown out like a candle flame, life seeped gradually away from the wholly alive until they finally became wholly dead, when all the flesh 
had rotted away and their social presence among the living had ebbed. This process could take a year or more. Second, in an age before anaesthetics or effective infection control, and when even simple surgery involved agonising pain and a good chance of dying anyway from septicaemia or blood loss, there was no context in which the scalpel in the skin was not terrifying.

As surgeon Edward May lamented in 1603, anatomy was greatly impeded because the common people of the country would not allow their bodies to be investigated because they believe 'their children or friends murdered after they are dead, if a surgeon should but pierce any part of their skin with a knife'. ${ }^{2}$

Cultural productions such as art and literature used the criminal corpse to evoke strong emotional reactions, which could be turned to comic effect or developed as horror. But the existence of cultural works around the criminal body also constituted part of what made it such a fearful, repulsive and powerful thing.

The deeply disturbing cultural resonance of post-mortem punishment informed, in a way that was rarely if ever articulated, contemporary anxieties about the ethical treatment of the dead body. The final chapter of this book will consider how the dread of something after death continued to affect public attitudes and policy long after the end of the Murder Act, as well as the way that new narratives were sometimes able to contest the meaning, and even the very definition, of a criminal corpse.

\section{Notes}

1. Shelley, M. (1823), Frankenstein: Or, the Modern Prometheus (London: Penguin Books), quote at p. 91.

2. See, Tarlow, S. (2007), The Archaeology of Improvement in Britain 17501850 (Cambridge: Cambridge University Press).

3. See, the first essay of Robert Owen's (1817), The Human Character: Preparatory to the Development of a Plan for Gradually Ameliorating the Condition of Mankind (London: Printed for Longman, Hurst, Rees, Orme, and Brown).

4. See Driver, F. (1988), 'Moral Geographies: Social Science and the Urban Environment in Mid-Nineteenth Century England', Transactions of the Institute of British Geographers, Vol. 13, 275-287; Cowling, M. (1989), The Artist as Anthropologist: The Representation of Type and Character in Victorian Art (Cambridge: Cambridge University Press). 
5. See, Sawday, J. (1995), The Body Emblazoned: Dissection and the Human Body in Renaissance Culture (London: Routledge).

6. The best extended consideration of Donne's interest in early modern anatomy remains Jonathan Sawday's (1995), The Body Emblazoned: Dissection and the Human Body in Renaissance Culture (London: Routledge).

7. See, Andrews, W. (1899), Bygone Punishments (London: W. Andrews \& Company), pp. 51-52. It is possible that Grindrod's story is the original because it was the subject of a popular ballad that was published in 1855 in W. Harrison Ainsworth's Ballads: Romantic, Fantastical and Humorous (London: Routledge), and it is certainly plausible that variants of this pleasing story were attached to gibbets in other localities.

8. See, Percy, R., Timbs, J., and Limbird, J. (1830), The Mirror of Literature, Amusement and Instruction: Vol. 15 (London: J. Limbird), pp. 210-213.

9. Ibid., quote at p. 211.

10. See, Chassaigne, P. (1999), 'Popular Representations of Crime: The Crime Broadside-A Subculture of Violence in Victorian Britain', Crime, History \& Societies, Vol. 3, Issue 2, 23-55.

11. See, Hood, T. (1831), The Dream of Eugene Aram, The Murderer (London: Charles Tilt).

12. See, Bulwer Lytton, E. (1832), Eugene Aram. A Tale (London: Henry Colburn and Richard Bentley).

13. Wodehouse, P.G. (1916), Jeeves Takes Charge.

14. Dickens, C. (1861), Great Expectations.

15. All we know of the gibbet is that it once held a pirate. The relevant sentences read: 'On the edge of the river I could faintly make out the only two black things in all the prospect that seemed to be standing upright; one of these was the beacon by which the sailors steered,-like an unhooped cask upon a pole, - an ugly thing when you were near it; the other, a gibbet, with some chains hanging to it which had once held a pirate. The man [Magwich] was limping on towards this latter, as if he were the pirate come to life, and come down, and going back to hook himself up again.'

16. Dickens, C. (1859), A Tale of Two Cities.

17. See, 'Book Twelfth', in Wordsworth, W. The Prelude; or, Growth of a Poet's Mind: An Autobiographical Poem.

18. See, Wu, D. (2012), Romanticism: An Anthology (Oxford: WileyBlackwell, 4th Edition).

19. See, Kelley, T.M. (1988), Wordsworth's Revisionary Aesthetics (Cambridge: Cambridge University Press), p. 120. 
20. Gwynplaine was later played by Conrad Veidt in a 1928 film adaptation of Hugo's novel, titled 'The Man Who Laughs', and has been cited as the inspiration for the DC Comics character, The Joker.

21. John Aitken, known as Jack the Painter, was executed and hung in chains in $\mathbf{1 7 7 7}$ for arson at Portsmouth docks, in a case that attracted a great deal of press attention.

22. One of these might have been Thomas Brett executed in 1789 for piracy and hung in chains at Dover Castle. Although Brett was one of a group of defendants all executed in relation to the same offence, he was the only one ordered to be hung in chains at Dover; the others were to be displayed along the Thames.

23. Hugo, V. (1870), By Order of the King (London: Bradbury, Evans \& Co. English Translation), quote at p. 85.

24. Ibid., p. 84.

25. Ibid., quote at p. 87.

26. Ornithologically unlikely; maybe rooks were intended.

27. Hugo, V. (1870), By Order of the King (London: Bradbury, Evans \& Co. English Translation), quote at p. 89.

28. Housman, A.E. Poem IX, A Shropshire Lad.

29. Sherwood (1822), The History of the Fairchild Family (London: J. Hatchard and Son).

30. See, Sugg, R. (2007), Murder After Death: Literature and Anatomy in Early Modern England (London: Cornell University Press), pp. 213-216.

31. See, Sawday, J. (1995), The Body Emblazoned: Dissection and the Human Body in Renaissance Culture (London: Routledge).

32. Pope, A. (1742), The Works of Alexander Pope, Esq; Vol III. Part II (London: R. Dodsley), quote at pp. 61-62.

33. Aries, P. (1981), The Hour of Our Death (Harmondsworth: Peregrine), p. 367.

34. See, Sugg, R. (2007), Murder After Death: Literature and Anatomy in Early Modern England (London: Cornell University Press); Davies, O. and Matteoni, F. (2017), Executing Magic in the Modern Era: Criminal Bodies and the Gallows in Popular Medicine (Palgrave Macmillan); Brittain, R.P. (1965), 'Cruentation: In Legal Medicine and in Literature', Medical History, Vol. 9, Issue 1, 82-88.

35. Brittain, R.P. (1965), 'Cruentation: In Legal Medicine and in Literature', Medical History, Vol. 9, Issue 1, 82-88.

36. In Act I, Scene II, the dead Henry VI's wounds begin to bleed when Gloucester (his murderer) enters the scene. See, Lull, J. ed. (1999), King Richard III (Cambridge: Cambridge University Press), p. 63.

37. Scott, W. (2001), Fair Maid of Perth, (Classic Books Company Edition), p. 89. 
38. See, Brittain, R.P. (1965), 'Cruentation: In Legal Medicine and in Literature', Medical History, Vol. 9, Issue 1, 86.

39. See, Davies, O. and Matteoni, F. (2017), Executing Magic in the Modern Era: Criminal Bodies and the Gallows in Popular Medicine (Palgrave Macmillan).

40. See, McCorristine, S. (2017), Interdisciplinary Perspectives on Mortality and Its Timings (Palgrave Macmillan).

41. See, Scott, W. (1995), The Antiquary (Edinburgh Edition of the Waverley Novels, 3), p. 138.

42. See, Matteoni, F. (2016), 'The Criminal Corpse in Pieces', Mortality, Vol. 21, Issue 3, 198-209; Davies, O. and Matteoni, F. (2015), "A Virtue Beyond All Medicine": The Hanged Man's Hand, Gallows Tradition and Healing in Eighteenth- and Nineteenth-Century England', Social History of Medicine, Vol. 28, Issue 4, 686-705; Davies, O. and Matteoni, F. (2017), Executing Magic in the Modern Era: Criminal Bodies and the Gallows in Popular Medicine (Palgrave Macmillan).

43. See, McCorristine, S. (2017), Interdisciplinary Perspectives on Mortality and Its Timings (Palgrave Macmillan).

44. See, Davies, O. and Matteoni, F. (2017), Executing Magic in the Modern Era: Criminal Bodies and the Gallows in Popular Medicine (Palgrave Macmillan).

45. See, Byrne, G. (2010), Spiritualism and the Church of England, 18501939 (Woodbridge: The Boydell Press), p. 90.

46. See, Kemp, M. (2010), 'Style and Non-style in Anatomical Illustration: From Renaissance Humanism to Henry Gray', Journal of Anatomy, Vol. 216, Issue 2, 192-208.

47. See, Heckscher, W.S. (1958), Rembrandt's Anatomy of Dr. Nicolaas Tulp, an Iconological Study (New York: New York University Press).

48. See, Sugg, R. (2007), Murder After Death: Literature and Anatomy in Early Modern England (London: Cornell University Press), pp. 19-35.

49. See, Sawday, J. (1995), The Body Emblazoned: Dissection and the Human Body in Renaissance Culture (London: Routledge), p. 62.

50. See, Passion of the Christ (2004) [film], dir. Mel Gibson (USA: Icon Productions); Braveheart (1995) [film], dir. Mel Gibson (USA: Icon Productions).

51. McArthur, C. (2003), Brigadoon, Braveheart and the Scots: Scotland in Hollywood Cinema (London: I.B. Tauris \& Co.).

52. Edward May Most certain and true relation, cited in Sugg, R. (2007), Murder After Death: Literature and Anatomy in Early Modern England (London: Cornell University Press), p. 20. 
Open Access This chapter is licensed under the terms of the Creative Commons Attribution 4.0 International License (http://creativecommons.org/licenses/ by $/ 4.0 /$ ), which permits use, sharing, adaptation, distribution and reproduction in any medium or format, as long as you give appropriate credit to the original author(s) and the source, provide a link to the Creative Commons license and indicate if changes were made.

The images or other third party material in this chapter are included in the chapter's Creative Commons license, unless indicated otherwise in a credit line to the material. If material is not included in the chapter's Creative Commons license and your intended use is not permitted by statutory regulation or exceeds the permitted use, you will need to obtain permission directly from the copyright holder.

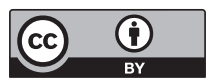

